\title{
東京 5 区内のオフィスビルへのテナント入居と空室期間に関する分析 AN ANALYSIS OF OCCUPANCY AND VACANCY LENGTHS OF TENANTS IN OFFICE BUILDINGS IN TOKYO FIVE WARDS
}

\author{
瀧 澤重 志*，松原 周 平**，加藤 直 樹***，小林 篤 司**** \\ Atsushi TAKIZAWA, Shuhei MATSUBARA, Naoki KATOH \\ and Atsushi KOBAYASHI
}

\begin{abstract}
In this article, we analyze the occupancy length and vacancy length of tenants located in 52 rental office buildings in main five wards of Tokyo by using survival analysis. Since the rental office market tends to change periodically, we model the phenomenon of the periodic change of 2-dimentional time-series data of tenant and vacancy rate by the ellipse approximation method.

Average occupancy length is about 13 years. Attributes contributing to the increase of the occupancy length are building age and image of the rental room and etc. Average vacancy length is about 88 days. Attributes contributing to the decrease of vacancy length are good rental room image, high land price per floor-space ratio and the market condition such that its state is recovery or boom state, and etc.
\end{abstract}

Keywords: office building, tenant, occupancy length, vacancy length, survival analysis, real-estate market analysis オフィスビル，テナント，入居期間，空室期間，生存時間分析，不動産市況分析

\section{1. はじめに}

証券投資信託法の改正などを受け，不動産の証券化等により不動 産投資信託が証券市場へ上場し市場を拡大してきた。同時に，バブ ル崩壊以前のような不動産の売却益のみに偏った評価ではなく，運 用益を重要視した評価がなされるようになった。オフィスビルから 生じる運用益は主として賃料収入であり，そこから管理費などを引 いた金額が収益となる．2008 年後半のサブプライムローンが原因の リーマンショックに端を発する世界的な景気後退の波を受けて，そ れまで活況を呈していた不動産市場は下火となり，空室率の増加や 賃料の下落によりオフィスビルの収益は低下した。オフィスビルの 収益は，このようなマクロな景気変動の影響を受けることは避けら れないが，その大きな変化の中で如何に収益性を安定して確保する かが，極めて重要な目標となる。

オフィスビルをはじめとする商業ビルでは，将来獲得される利益 をその不動産の価值とみな寸収益還元法によってその価值が測られ ることから, 将来そのビルから得ることのできる利益についてより 正確に把握寸ることが重要となる。しかし不動産は個別性が強く, さらに個別の成約事例についての情報を関係者以外が知ることは難 しいため, 将来得ることのできる利益に基づく客観的な価值評価は 困難であり, 不動産業従事者の勘や経験に依存する部分が大きい. このような状況に対して, 収益を構成する因子である賃料の推定
についてこれまで多くの分析がなされてきた ${ }^{1-3)}$. 筆者らも, オフィ スビルの賃料が人の主観的評価に有意に関わっている事を明らかに した ${ }^{4)}$ 。さらにその結果を受けて, 感性評価がどのようなビルの属 性と関係しているのかも明らかにした ${ }^{5)}$.

しかし高い収益を得るにはある時点の賃料収入を分析するだけで は不十分で, 安定的, 継続的な収益の確保も重要な視点になる。こ れはビル内の空室の発生をできるだけ抑制し，入居テナントから， その時々の市況, 地域, ビルスペック等に照らし合わせて適正な賃 料を継続的に確保することによって実現される．このために，新規 契約や契約更新時に行われる貨料の交渉，適切なタイミングとコス トをかけたビルの管理・修繥, 新規に入居するテナントに関する効 果的なデユーデリジェンス（査定）とリーシング（テナント誘致） など，様々な業務戦略を考慮する必要があり，この意思決定の基礎 資料として，テナントの入居期間や空室期間に関する知見は有益で ある.しかしこのテーマに関する調查・研究は殆ど行われていない。

以上の背景から本研究では, 東京都区内に立地する中規模のオフ イスビルの貸室へのテナントの入居期間と空室期間の分析を行う。 分析に用いるテナントに関するデータには, データの対象期間の後 で入居や空室が継続し，入居，空室期間が確定しないものが少なか らず存在する．このようなデータは打ち切りデータと呼ばれ，一般 的な統計解析の手法では分析が難しいが，本研究では打ち切りデー

\footnotetext{
* 京都大学大学院工学研究科建築学専攻 助教·博士(工学) Assistant Prof., Dept. of Arch. and Architectural Eng., Grad. Sch. of Eng., Kyoto Univ., Dr. Eng.

The Japan Research Institute, Limited, M. Eng.

** 日本総研(株) 修士 (工学)

$* * *$ 京都大学大学院工学研究科建築学専攻 教授.工博

Prof., Dept. of Arch. and Architectural Eng., Grad. Sch. of Eng., Kyoto Univ., Dr. Eng.

**** 京都大学大学院工学研究科建築学専攻 大学院生

Graduate Student, Dept. of Arch. and Architectural Eng., Grad. Sch. of Eng., Kyoto Univ.
} 
タがあっても分析が可能な生存時間分析 ${ }^{6)}$ と呼ばれる手法を用いて 分析を行う. 生存時間分析は医療分野や信頼性工学の分野を中心に 用いられており，死亡や故障といった事象をイベントとよび，その 発生率をハザード関数としてモデル化し，イベントが発生するまで の期間やイベントの発生因子について分析するものである．建築学 の分野では, 小松らによって建物寿命の推定に関する様々な研究が 行われており，例えば本研究で用いる Kaplan-Meier 推定法 ${ }^{7}$ を用い

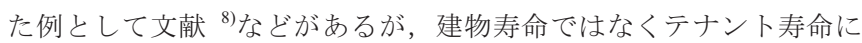
ついての研究は行われていない，テナントの寿命に関連する研究と しては，伊藤らによる都市スケールでの商業系テナントの交替の研 究 ${ }^{9}$ がある.この研究では, テナントの入居日数の確率分布を情報 量に基づく独自のモデルにより推定しているが，都市スケールの分 析で, テナントが入居する建物との関係は考慮されていない.

本研究では, 生存時間分析の中で, 生存率曲線を求める Kaplan-Meier 推定法と, 生存時間に影響を与える因子を分析する Cox 比例ハザードモデル ${ }^{10)}$ を用いる。ちなみに本研究における生存時間 は，テナントの入居期間もしくは空室期間に該当する. Cox 比例八 ザードモデルは，比例八ザード性という仮定のもとで，生存時間に 複数の属性が与える影響を同時に捉えようとする手法である．比例 八ザード性とは，二つの属性が異なるサンプルの八ザードの比が， 八ザード関数によらずサンプルの属性の違いだけに依存するという 仮定である.この手法は，注 2)に示すように八ザード関数を陽に考 慮しないので八ザードを具体的に予測することはできないが，各属 性が八ザードに与える相対的な影響の大小を調べるのに用いられる 八ザードを予測するには，ハザード関数を指数分布等に定めたパラ メトリックな生存時間分析手法を用いる。本研究では，ハザードの 予測ではなく各変数の相対的な影響度を調べることが目的なので, 関数形の仮定が不要な Cox 比例ハザードモデルを用いる.

Kaplan-Meier 推定法を用いた分析では，テナントの入居期間と空 室期間の平均やテナントや空室の残存確率の変化の傾向を明らかに する. Cox 比例ハザードモデルを用いた分析では, 説明変数として 立地属性, 建物属性, 感性評価属性など既往研究 ${ }^{4) 5}$ で用いたデー夕 に加え, テナント業種と, オフィスビルマーケットのモデルから得 られる属性を付与し, 多様な観点から入居期間と空室期間の分析を 行う。ちなみにオフィスビルマーケットを分析した既往研究として 村山らの研究 ${ }^{11}$ がある, この研究では, 賃貸オフィスビルのストッ ク面積, 賃料, 空室率とそれらの変化量から, 国内の各地域のオフ イスビルマーケットの類型化と国際比較を行っている. それに対し て本研究では, 同種のデータを用いつつも, 東京都区内のオフィス 市況の時系列変化をモデル化する点で異なる.

以降, 2 章では使用するデータの概要について, 3 章では市況のモ デル化方法について, 4 章で生存時間分析の概要について述べる. そして，5 章で入居期間の分析を，6 章で空室期間の分析を行い， 7 章でまとめとする.

\section{2. データ}

本研究で用いるデータソースを表 1 に示寸。本研究では, 大手プ ロパティマネジメント会社が管理を委託されている東京都内のオフ イスビル 52 件について, 2001 年 4 月から 2009 年 4 月の 8 年間のテ ナントの入退去に関するデータ（\#1）を中心に分析する。このデー
表 1 使用したデータソース

\begin{tabular}{|c|c|}
\hline 名称 & 備考 \\
\hline \#1. テナント入居データ & $\begin{array}{l}\text { 出典: (株)ザイマックス, 東京都主要 } 5 \text { 区内 } \\
\text { のオフィスビル } 52 \text { 棟, } 2001 \text { 年 } 4 \text { 月〜2009 年 } \\
4 \text { 月, 表 } 2,4 \text { の “賃室” 分類に対応, }\end{array}$ \\
\hline $\begin{array}{l}\text { \#2. オフィスビル基本デ } \\
\text { ータ }\end{array}$ & $\begin{array}{l}\text { 出典：(株)ザイマックス, “建物”, “エリア” } \\
\text { に対応 }\end{array}$ \\
\hline $\begin{array}{l}\text { \#3. オフィスエリア市況 } \\
\text { データ }\end{array}$ & $\begin{array}{l}\text { 出典：CREIS Japan, } 2001 \text { 年 } 3 \text { 月〜2009 年 } 3 \\
\text { 月, “市況” に対応 }\end{array}$ \\
\hline \#4. 感性調査データ & $\begin{array}{l}\text { 出典：(株)ザイマックス, } 2007 \text { 年調査 (学生 } \\
\text { 調査員 } 5 \text { 名の平均值), “感性調査” に対応 }\end{array}$ \\
\hline \#5. テナント業種データ & $\begin{array}{l}\text { 出典 : 帝国データバンク HP 検索＋その他の } \\
\text { インターネット検索, “業種” に対応 }\end{array}$ \\
\hline
\end{tabular}

夕は 1 ケ月毎に更新され，テナントの契約状況の変化を追跡するこ とができる，データは当該プロパティマネジメント会社がビルの管 理を委託された時点から蓄積されるが，それ以前からテナントが入 居している場合, その期間の情報は不明である. しかし, テナント がビルに入居する契約を結んだ日の情報に関しては引き継がれてお り, 本研究ではこの日を入居開始日としている。しばしば貸室が併 合, 分割されているが, 時系列で分析するために貸室の親子関係を 整理してデータ化した．なお，分析に用いる入居期間と空室期間の 単位は日である。

このデータに，建物の基本データ（\#2） と感性調査データ（\#4） を加えた. 感性調查は, 建物の内観と外観に関して, 2007 年に 5 名 の学生調查員により行った主観的調查であり, 既往研究 ${ }^{45)}$ でも類似 の感性調查を行っている.ここでは 2007 年の調査データを用いるが, 分析では絶対值ではなく相対的な比較が重要になるので，調查期間 とデータ期間に時間差があっても大きな問題はないと考えた. また, 5.2 と 6.2 で基本的な Cox 比例八ザードモデルを用いるが, このモデ ルでは通常，説明変数を時間によらず一定として扱うので，本研究 もその仮定に従っている.

さらに，テナントの入居期間の分析では，テナントの業種を考慮 するために，大手信用調査会社のウェブサイトにある無料の企業情 報の検索ページを利用して業種を調查し，その企業の 3 段階ある業 種分類のうち, 最も粗い分類をテナントの業種データとした (\#5). なお，このページで調べることができなかった企業については，一 般的なインターネット検索により調查し, それでも特定できなかっ たものは業種不明として扱った. 業種以外にも, 設立年, 従業員数, 資本金，業績の変化など様々なテナント情報が市販されているが, 倒産等で詳細な企業情報が不明なテナントが多かったため, それら に比べて網羅的にデータが得られた業種のデータのみを利用した． さらに空室期間の分析では, 空室発生時のオフィスビルマーケット の市況を考慮するが，これについては次章で述べる。

\section{3. 空室率と賃料の変化から見た市況分類}

\section{1 背景}

経済状況，空室率，募集賃料の間には高い相関があると考えられ る，たとえば景気が悪化すると借り手が減り空室率が上がる，そう なるとビルオーナーは募集賃料を下げ空室を埋めようとする，逆に 景気が回復しだすと空室率が下がり，募集賃料は上がる。つまり， 景気の循環 ${ }^{12)}$ のうに, 空室率と募集賃料の関係も周期的に変化す ると考えられる。この関係を表 1 の\#3 の不動産市況データを用いて 


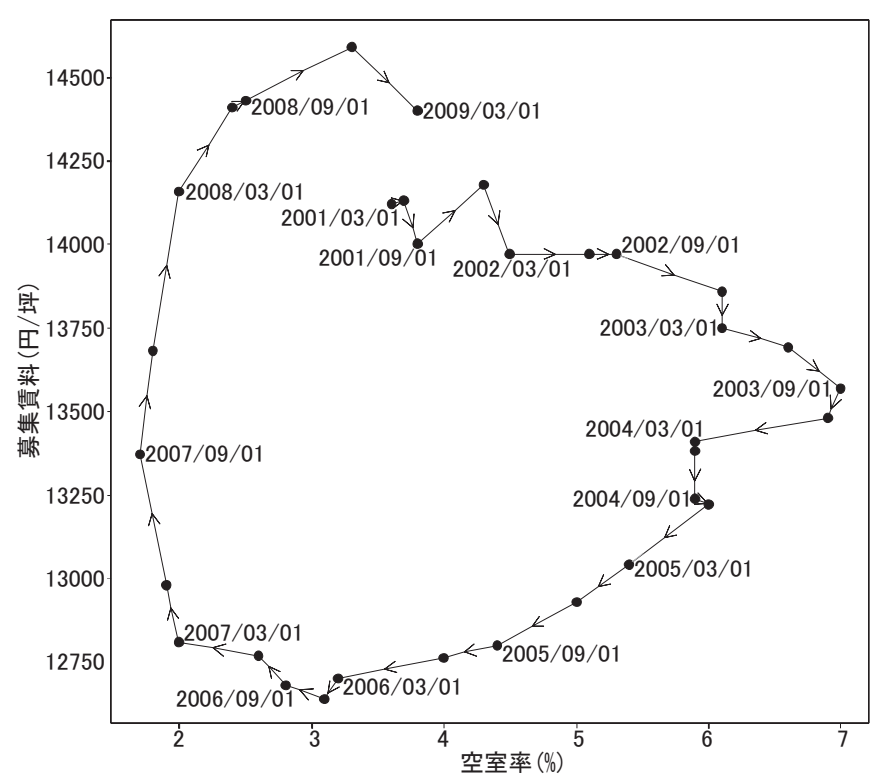

図 1 東京 23 区内のオフィスエリアの空室率と募集賃料の変化

(2001 年 3 月～ 2009 年 3 月)

説明する. 本研究で利用するのは 4 半期毎に集計されている東京 23 区内のビルの平均の募集賃料と空室率の集計である. 図 1 に, 今回 の分析に合わせ 2001 年 3 月〜2009 年 3 月の期間のデータを, 横軸 が空室率，縦軸が募集賃料の散布図にプロットし，時系列でつない だものを示す。この図から，約 8 年の間にほぼ時計回りに一周する ような軌道を描いているのがわかる.このような周期的な関係は, 社会・経済構造やビルのストックの変化などがあるので, 長期的に 同じ軌道で安定しているとはいえないが，10 年程度の短期間であれ ばある程度成立する関係であると仮定して，モデル化を行う。

\section{2 モデル化}

この周期的な変化をモデル化するために, 空室率 $(x)$, 募集賃料 (y) のペアからなる時系列データを $x-y$ 平面上にプロットした とき，その点列を楕円で近似する。

既存の楕円の近似手法としては, 確率楕円と呼ばれる手法がある. 例えば，平面の場合は 2 次元正規分布などによって, データの密度 関数を推定するが，これは楕円の中心部ほど発生密度が高くなるモ デルなので, 本研究で目的とする楕円の境界部分へのデータのフィ ッティングには適さない. 楕円の境界部分にデータをフィッティン グさせる手法としては，一般には最小 2 乗法が用いられる。この方 法は惑星の軌道の観測データなど，点列がほぼ棈円上にあり，デー タが軌道上から満遍なくサンプリングできるような場合には有効だ が，そのような前提が成立しないデータに適用した場合，得られる 楕円が極端に大きくなってしまうなどの問題がある. 今回用いるデ 一夕は図 1 に示すように周期的な軌道を示すが，きれいな楕円軌道 とはなっていないため, 上記の問題が起こる可能性がある.

そこで本研究では図 2 のように, 平面上の点集合を中心の座標が 同じで軸平行な大小 2 つ楕円で挟み，その中間の楕円として，点 集合の軌道を近似することで，大きさが極端な楕円が生成されにく い方法を提案する. なお, データの点集合の分布から回転は考慮し ないものとする．また今回は点の時系列としての連続性は考慮しな い.

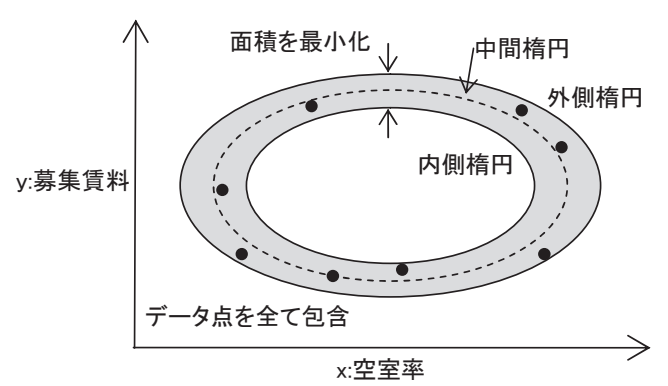

図 2 募集賃料と空室率に関する楕円近似の概念図

モデル化の説明に移ろう。まず大小二つの楕円の方程式を， $a, b, c, d, d^{\prime}$ をパラメータとして

$$
\begin{aligned}
& x^{2}+a y^{2}+2 b x+2 c y=d \\
& x^{2}+a y^{2}+2 b x+2 c y=d^{\prime} \quad\left(d^{\prime} \geq d\right)
\end{aligned}
$$

とする.この楕円近似の問題は, 各データ点が 2 つの楕円に囲まれ る領域に入っていることを制約条件とし，2 つの楕円によって囲ま れる面積を最小化する問題として定式化できる. 2 つの棈円に囲ま れる面積は

$$
\frac{\left(d^{\prime}+b^{2}+\frac{c^{2}}{a}\right)}{\sqrt{a}}-\frac{\left(d+b^{2}+\frac{c^{2}}{a}\right)}{\sqrt{a}}=\frac{\left(d^{\prime}-d\right)}{\sqrt{a}}
$$

となるので, $a, b, c, d, d^{\prime}$ に関して以下の非線形最小化問題を解けば よい.

$$
\begin{array}{ll}
\text { Minimize } & \frac{\left(d^{\prime}-d\right)}{\sqrt{a}} \\
\text { subject to } & x_{i}^{2}+a y_{i}^{2}+2 b x_{i}^{2}+2 c y_{i} \geq d, i=1, \ldots, n \\
& x_{i}^{2}+a y_{i}^{2}+2 b x_{i}^{2}+2 c y_{i} \leq d^{\prime}, i=1, \ldots, n
\end{array}
$$

ここで， $x_{i}$ は期間 $i$ の空室率データ, $y_{i}$ は募集賃料のデータ, $n$ はデータの件数を示す. 得られる中間楕円は $d^{\prime \prime}=\left(d+d^{\prime}\right) / 2$ で, ほかのパラメータは大小の棈円のパラメータと同じである.

この手法に関連して，筆者らの既往研究では，東京都区内のそれ ぞれのオフィスエリアの市況データから楕円近似モデルを作成し， そのパラメータをクラスタリングし 5 つの地域にオフィスエリアを 分類した ${ }^{13}$. 本研究では 6 章の空室期間の分析で市況を考慮するが, 近似楕円のパラメータは 4 つあって独立して扱うと市況がとらえに くいため, 図 3 のように棈円軌道から市況を不況 $\rightarrow$ 回復 $\rightarrow$ 好況 $\rightarrow$ 後 退の 4 つの状態に分割してデータとして用いることにした．不況は 空室室が大きいまま募集賃料が低下していく状態，回復は募集賃料 があまり変化しないが空室率が低下していく状態，好況は空室率が 低い状態で募集賃料が上昇していく状態，後退は募集賃料があまり 変化しないが空室率が上昇していく状態に対応する. 市況の区分を 行うために, 求められた棈円を散布図上で円になるよう軸のスケー ルを変換し，楕円の中心を通り $x$ 軸に対して \pm 45 度方向に伸びる 直線により, 元のデータ系列が分割される期間で大まかに市況を分 割する。 


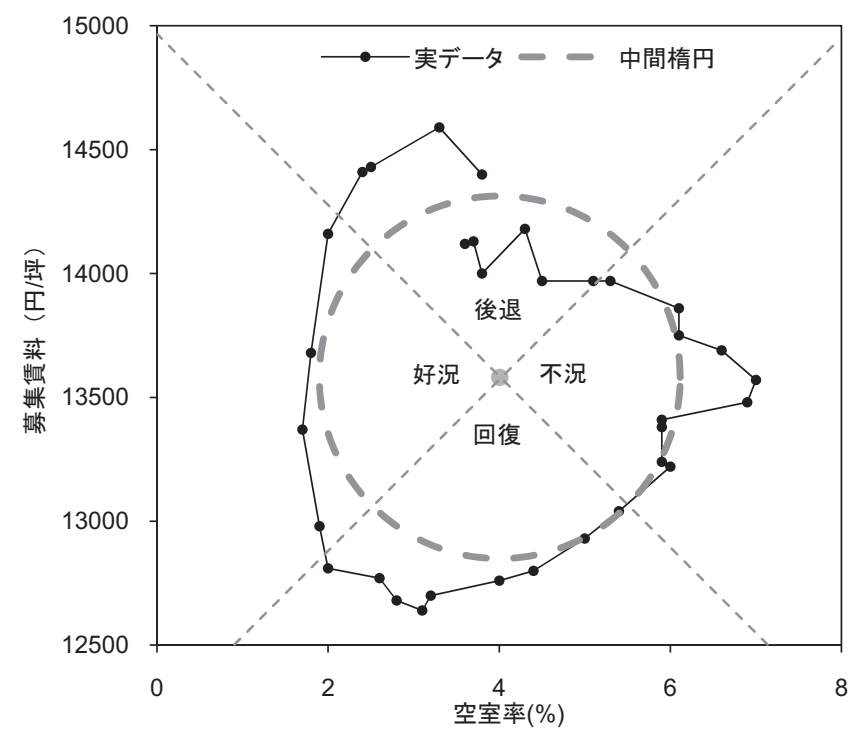

図 3 楕円近似による東京 23 区の 2001 年 3 月〜2009 年 3 月の市況

\section{3 計算}

表 $1 \# 3$ のデータを用いて, 上記の問題を数理計画ソフト NUOPT Ver.11 を用いて解いた。 得られた中間楕円は, 中心の $(x, y)$ 座標が $(4.006,13581)$, 中心から $(x, y)$ 軸方向の辺の長さが $(2.110,731.8)$ である (図 3). 上記の方法で市況区分を求めた結果，おおよそ，後 退 $=\{2001 / 6 / 1 \sim 2002 / 6 / 30,2008 / 4 / 1 \sim\}$, 不況 $=\{2002 / 7 / 1 \sim 2005 / 1 / 31\}$, 回復 $=\{2005 / 2 / 1 \sim 2007 / 3 / 31\}$, 好況 $=\{2007 / 4 / 1 \sim 2008 / 3 / 31\}$ の期間 に分割された。

\section{4. 生存時間分析}

ここでは生存時間分析の基本的な概念である生存率と八ザード関 数について述べる ${ }^{6}$.

まず, 生存期間を表す非負の確率変数を $T$ とする. $S(t)=$ $\operatorname{Pr}\{T \geq t\}$ を生存率関数と呼び, 調查サンプルが時間 $t$ の直前まで 生存している確率を示す。また, $t$ における死亡率 $F(t)$ は $F(t)=1-S(t)$ となる.

本研究で対象とする連続時間の場合について, いま, $t$ の直前ま で生存したサンプルが, 次の $\Delta t$ の期間に死亡するとき, その単位 時間あたりの平均死亡率は次式で表される.

$$
\frac{\operatorname{Pr}\{t \leq T<t+\Delta t \mid T \geq t\}}{\Delta t}
$$

なお上式は， $T \geq t$ という条件付き確率になっている.上式におい て $\Delta t \rightarrow 0$ としたときの極限值を $t$ における八ザード $h(t)$ と呼 ぶ. 寸なわち

$$
\begin{aligned}
h(t) & =\lim _{\Delta t \rightarrow 0} \frac{\operatorname{Pr}\{t \leq T<t+\Delta t \mid T \geq t\}}{\Delta t} \\
& =\lim _{\Delta t \rightarrow 0} \frac{S(t)-S(t+\Delta t)}{S(t) \Delta t} \\
& =\frac{1}{S(t)} \lim _{\Delta t \rightarrow 0} \frac{F(t+\Delta t)-F(t)}{\Delta t} \\
& =\frac{1}{S(t)} \frac{d F(t)}{d t}
\end{aligned}
$$

\begin{tabular}{|c|c|c|c|c|c|c|}
\hline 分類 & 変数 & 最小 & 平均 & 最大 & 標準偏差 & 件数 \\
\hline \multirow{6}{*}{ エリア } & エリア=新宿区 & & & & & 66 \\
\hline & エリア=千代田区 & & & & & 324 \\
\hline & エリア=中央区 & & & & & 183 \\
\hline & エリア=港区 & & & & & 400 \\
\hline & エリア=渋谷区 & & & & & 30 \\
\hline & $\begin{array}{l}1 \text { 種あたり価格（千円 } \\
\left.100 / \mathrm{m}^{2} / \text { 容積率 }\right)\end{array}$ & 79 & 342 & 1,171 & 207 & \\
\hline \multirow{10}{*}{ 建物 } & 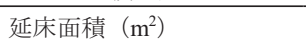 & 417 & 1,672 & 4,360 & 1,090 & \\
\hline & 基準階面積（m²） & 20 & 134 & 516 & 97 & \\
\hline & 地上階数 & 5.0 & 9.1 & 13.0 & 1.6 & \\
\hline & 地下階数 & 0.0 & 1.1 & 4.0 & 0.9 & \\
\hline & 退去時築年数 & 0.7 & 21.6 & 44.8 & 11.9 & \\
\hline & ELV 台数 & 1.0 & 2.1 & 4.0 & 0.9 & \\
\hline & 空調方式=個別 & & & & & 721 \\
\hline & 空調方式=セントラル & & & & & 207 \\
\hline & 空調方式=混在 & & & & & 75 \\
\hline & 光ケーブル=有 & & & & & 359 \\
\hline \multirow{5}{*}{ 感性評価 } & エントランスイメージ & 2.4 & 4.4 & 5.0 & 0.6 & \\
\hline & エレベータイメージ & 1.8 & 4.0 & 4.8 & 0.5 & \\
\hline & 基準階イメージ & 2.0 & 4.1 & 4.8 & 0.6 & \\
\hline & トイレイメージ & 1.0 & 4.1 & 5.0 & 0.8 & \\
\hline & 外観イメージ & 2.8 & 4.3 & 5.0 & 0.5 & \\
\hline \multirow{8}{*}{ 貨室 } & 入居年数 & 0.0 & 5.9 & 48.2 & 5.9 & \\
\hline & 退去イベント=有 & & & & & 539 \\
\hline & 階数 & -3.0 & 4.4 & 13.0 & 3.0 & \\
\hline & 実効面積 & 0.6 & 85.1 & 469.7 & 61.8 & \\
\hline & 用途=事務所 & & & & & 878 \\
\hline & 用途=店舗 & & & & & 78 \\
\hline & 用途=倉庫 & & & & & 37 \\
\hline & 用途=その他 & & & & & 10 \\
\hline \multirow{9}{*}{ 業種 } & 業種=サービス業 & & & & & 491 \\
\hline & 業種=卸売·小売業·飲食店 & & & & & 212 \\
\hline & 業種=製造業 & & & & & 90 \\
\hline & 業種=運輸·通信業 & & & & & 52 \\
\hline & 業種=建設業 & & & & & 16 \\
\hline & 業種=金融業·保険業 & & & & & 69 \\
\hline & 業種=不動産業 & & & & & 37 \\
\hline & 業種=公務·他 & & & & & \\
\hline & 業種=不明 & & & & & 34 \\
\hline
\end{tabular}

表 2 入居期間分析に使用する貸室延へ 1,003 室の変数の基礎統計

である. $\Delta t$ が小さいとき, $\Delta t \cdot h(t)$ は $t$ まで生存したサンプルが, 次の $\Delta t$ の期間に死亡する確率の近似となる。 $S(t)$ の関数型には, 指数分布やWeibull 分布が用いられることが多い.

具体的な推定方法である Kaplan-Meier 推定法と Cox 比例ハザード モデルについては，注 1) 2)を参照のこと.

\section{5. 入居期間の分析}

\section{1 対象データ}

テナントの入居期間を分析するので，テナントを分析の単位にす ることが自然と思われるが，同じビル内で複数の室を借りているテ ナントが少なからず存在し，さらに入居期間内で貸室の増減が見ら れることもあるため, テナント単位での分析は難しいと判断し, 貸 室単位で分析する.貸室単位では 1,003 件のテナント入居があった. ちなみにテナント単位では 583 件のテナントが存在した. 表 2 に貸 室毎の変数の基礎統計を示す。 1 種あたり価格は, 地価を容積率で 割ったものである. 貸室は事務所以外に店舗や倉庫等異なる用途で 使われる場合があるので, 用途の説明変数を設けて異なる用途のデ 


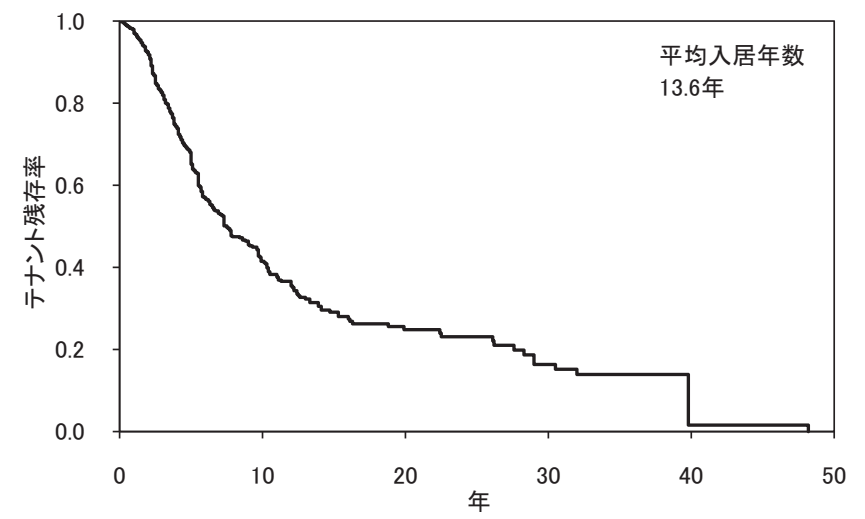

図 4 テナント残存率曲線

ータをまとめて分析を行っている. また， 3 章の市況のデータは 8 年程度の周期なので, それより長い入居期間の推定に用いるには無 理があるので, 入居期間の分析には市況のデータは用いない. なお, 感性評価は 1 が最低 5 で最高の評価となる。

\section{2 テナント残存率の Kaplan-Meier 推定}

上記データのうち入居年数と退去の変数を用いて, テナント退去 をイベントとして, Kaplan-Meier 推定法によりテナントの残存率曲 線を求めた結果を図 4 に示寸。使用ソフトはJMP8.02 である。平均 入居年数は 13 年程度である. なお, この值は表 2 のテナントの平均 入居年数 $(5.9$ 年) よりも長いが, Kaplan-Meier 推定法では, 打ち切 りデータでは残存率が低下しないので, 単純集計した場合よりも平 均值が長くなる.グラフの曲線を観察すると, 入居後 10 年程度まで は残存率の低下が急だが，それを過ぎると次第に緩やかになってい く、寸なわち，短期入居と長期入居のテナントに別れる傾向がある と考えられる.なお，40 年を過ぎて急激にテナント残存率が減少し ているのは，この時期に同一ビル内で多数の室を借りていた古くか ら入居していたテナントの退去があったためである。

\section{3 Cox 比例ハザードモデルによる退去リスクモデルの作成}

表 2 に示した説明変数を全て $[0,1]$ に基準化し, 統計解析ソフト R2.9.1の survival ライブラリに含まれる coxh 関数により Cox 比例八 ザードモデルを構築し，MASS ライブラリに含まれる stepAIC 関数 を用いて, AIC を評価規準として変数増減法により変数選択を行っ た注 ${ }^{3)}$. 得られた変数の組合せで, JMP 8.02 を用いて Cox 比例八ザ ードモデルにより退去リスクモデルを作成し，係数の推定值，その $\mathrm{p}$ 值, リスク比（含 $95 \%$ 信頼区間）等を求めた. その結果を表 3 に 示す。“エリア=渋谷区” と “業種=運輸・通信業”を除き, 他の変 数は $\mathrm{p}$ 值が有意水準 $5 \%$ を満たしている. また, 各変数のリスク比 とその $95 \%$ 信頼区間を図 5 に示す，リスク比は，各変数が最小值か ら最大值に変化した場合の退去ハザードの変化割合を示しており, その值が 1 より大きければ退去側に，1 より小さければ入居継続側 に働く変数であることを示す。これらの退去リスクが大きい変数は “業種=不動産業”である. 反対に継続因子となるのは, “退去時築 年数”が大きい, “外観イメージ”がよい, “用途=店舗” である. 古 いビルの退去リスクが低いことは, 古くからあるビルに継続的に入 居しているテナントが少なからずあることを示唆している.しかし， 外観イメージの高さが入居継続因子となっていることから, 単に古 くから入居しつづけるわけではなく, デザインの質, メンテナンス
表 3 退去リスクモデルのパラメータ

\begin{tabular}{|c|c|c|c|c|c|}
\hline \multirow[b]{2}{*}{ 項 } & \multirow[b]{2}{*}{ 推定值 } & \multirow[b]{2}{*}{$\mathrm{p}$ 值 } & \multicolumn{3}{|c|}{ リスク比 } \\
\hline & & & 值 & $\begin{array}{c}\text { 下側 95\% } \\
\text { 信頼限界 }\end{array}$ & $\begin{array}{l}\text { 上側 } 95 \% \\
\text { 信頼限界 }\end{array}$ \\
\hline 市区町村=港区 & 0.423 & 0.000 & 1.527 & 1.249 & 1.866 \\
\hline 市区町村=溙谷区 & 0.569 & 0.043 & 1.766 & 1.017 & 3.067 \\
\hline 1 種あたり価格 & 0.773 & 0.002 & 2.167 & 1.338 & 3.509 \\
\hline 退去時築年数 & -1.457 & 0.000 & 0.233 & 0.147 & 0.370 \\
\hline ELV 台数 & 0.356 & 0.032 & 1.428 & 1.031 & 1.978 \\
\hline 光ケーブル =有 & 0.178 & 0.091 & 1.195 & 0.972 & 1.469 \\
\hline 外観イメージ & -0.614 & 0.019 & 0.541 & 0.324 & 0.904 \\
\hline 用途=店舗 & -0.578 & 0.007 & 0.561 & 0.369 & 0.855 \\
\hline 業種=サービス業 & 0.335 & 0.002 & 1.398 & 1.133 & 1.725 \\
\hline 業種=運輸・通信業 & 0.418 & 0.027 & 1.518 & 1.048 & 2.201 \\
\hline 業種=不動産業 & 1.246 & 0.000 & 3.478 & 2.215 & 5.461 \\
\hline
\end{tabular}

モデルの $\mathrm{AIC}=5,417.5$

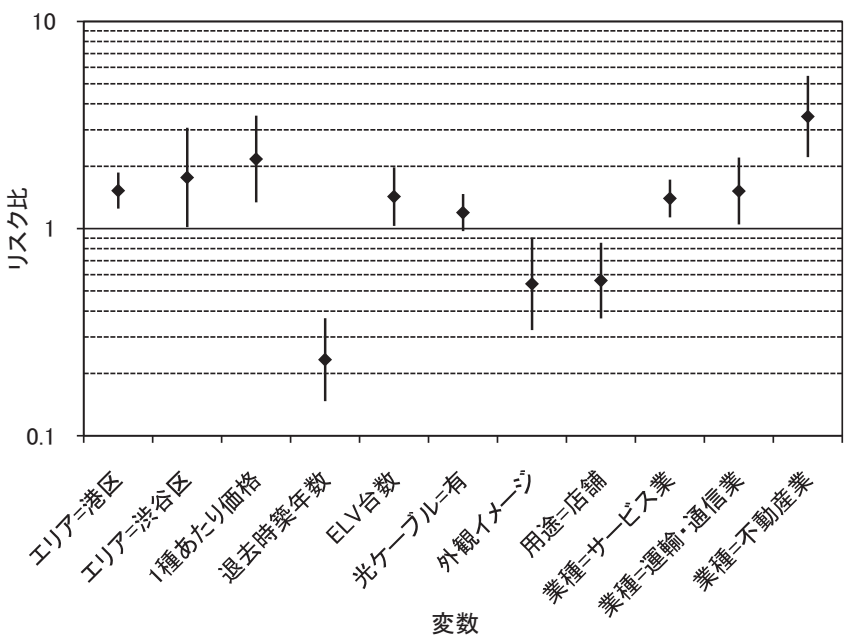

図 5 退去リスクモデルの説明変数のリスク比（含 $95 \%$ 信頼区間）

や改修の重要性が示唆される結果とも解勫できる。また，店舗は入 れ替わりが激しいイメージがあるが, 本研究で用いたデータに関し ていえば，オフィスビルに入居する店舗系テナントの場合は，事務 所系テナントなどと比較して長く入居する傾向があるという結果と なった.

\section{6. 空室期間の分析}

\section{1 データ}

次に空室期間の分析を行う。この分析も貸室単位で行う。生存時 間分析では死亡や退去など価值がネガティブな事象がイベントにな ることが多いが，ここでは空室が終了する，すなわちテナントが入 居寸るというポジティブな事象がイベントとなる点に注意してほし い. また 2 章で述べたように, 空室が発生せずにテナントが切れ目 無く入れ替わる場合は空室 0 日としている. 元のデータでは合計 578 件の空室が発生しており，その最長期間は 2,382 日となっていた. しかし共同研究を行うプロパティマネジメント会社から, 今回扱っ たビルでは 1 年以上の空室発生期間の場合は, 建物の改修などの人 為的な影響が作用している可能性が高いとの指摘を受けた。今回は すべての物件の改修データを確認することが難しかったので，本研 究では空室期間が 1 年以内のものに限って分析を行うことにした. この区分は一つの目安なので, 実際の平均空室日数は本報の結果よ 
表 4 空室期間分析に使用する空室延べ 493 室の変数の基礎統計

\begin{tabular}{|c|c|c|c|c|c|c|}
\hline 分類 & 説明変数 & 最小 & 平均 & 最大 & 標準偏差 & 件数 \\
\hline \multirow{4}{*}{ 市況 } & 市況=後退 & & & & & 144 \\
\hline & 市況=不況 & & & & & 193 \\
\hline & 市況=回復 & & & & & 95 \\
\hline & 市況=好況 & & & & & 61 \\
\hline \multirow{6}{*}{ エリア } & 区=新宿区 & & & & & 12 \\
\hline & 区=千代田区 & & & & & 162 \\
\hline & 区=中央区 & & & & & 70 \\
\hline & 区=港区 & & & & & 229 \\
\hline & 区=橴谷区 & & & & & 20 \\
\hline & $\begin{array}{l}1 \text { 種あたり価格（千円 } \times \\
\left.100 / \mathrm{m}^{2} / \text { 容積率 }\right)\end{array}$ & 79 & 335 & 1171 & 197 & \\
\hline \multirow{11}{*}{ 建物 } & $\begin{array}{l}\text { 平均賃料（円/坪，2007 年, } \\
\text { 共益費含） }\end{array}$ & 12,000 & 22,754 & $+40,000$ & 5,465 & \\
\hline & 延床面積 $\left(\mathrm{m}^{2}\right)$ & 417 & 1,740 & 4,360 & 1,151 & \\
\hline & 基準階面積（m²） & 20 & 143 & 516 & 114 & \\
\hline & 地上階数 & 5.0 & 9.1 & 13.0 & 1.6 & \\
\hline & 地下階数 & 0.0 & 1.0 & 4.0 & 0.9 & \\
\hline & 発生時築年数 & 5.5 & 23.2 & 45.1 & 11.8 & \\
\hline & ELV 台数 & 1.0 & 2.1 & 4.0 & 1.0 & \\
\hline & 空調=個別 & & & & & 343 \\
\hline & 空調=セントラル & & & & & 111 \\
\hline & 空調=混在 & & & & & 39 \\
\hline & 光ケーブル有 & & & & & 181 \\
\hline \multirow{5}{*}{ 感性評価 } & エントランスイメージ & 2.4 & 4.4 & 5.0 & 0.6 & \\
\hline & エレベータイメージ & 1.8 & 4.0 & 4.8 & 0.5 & \\
\hline & 基準階イメージ & 2.0 & 4.1 & 4.8 & 0.6 & \\
\hline & トイレイメージ & 1.0 & 4.2 & 5.0 & 0.7 & \\
\hline & 外観イメージ & 2.8 & 4.3 & 5.0 & 0.5 & \\
\hline \multirow{4}{*}{ 貸室 } & 空室日数 & 0 & 79 & 365 & 93 & \\
\hline & 入居イベント=有 & & & & & 442 \\
\hline & 階数 & -2.0 & 4.7 & 11.0 & 2.9 & \\
\hline & 実効面積 $\left(\mathrm{m}^{2}\right)$ & 2.6 & 85.9 & 469.7 & 59.6 & \\
\hline
\end{tabular}

りも長くなる可能性と, 条件が悪いために空室期間が 1 年を超える 貸室の分析がなされない可能性が残るが, これらの点の改善は今後 の課題としたい. 1 年以内の空室期間に限定した場合, 空室 0 日も 含めると 493 件の空室が発生した. 表 4 にこれらのデータの基礎統 計を示す．空室期間は複数の市況区間にまたがる場合もあるが，市況 の説明変数にはすべて空室発生時の市況分類を用いた。 なお，建物の 平均顀料は用いたデータの都合上 2007 年のものを用いているが, 感 性評価と同様にビル間の相対的な差異は調查年度を通じて大きく変 化しないと考え, 単年度のものを用いている. しかし貸室単位でみ ると, 空室期間が長くなるとオーナーがフリーレント（賃料無料期 間)を設定したり募集賃料を下げるといった行動が予想されるので, 今後の課題として, 貸室単位で各年度の賃料の推移を把握し, 時間 依存型の説明変数を考慮できる分析モデルの適用を検討したい.

\section{2 空室残存率の Kaplan-Meier 推定}

まず 5.2 と同様に, Kaplan-Meier 推定により空室残存率曲線を求 めそれを図 6 に示寸，空室日数が 0 日の場合が 4 割近くあるが，そ こから少しだけ,下に凸の軌道を描いて空室残存率が低下していく. しかし 1 年という期間で見れば，図 4 で見られたような極端な 2 極 化傾向はない.

\section{3 Cox 比例ハザードモデルによる入室リスクモデルの作成}

次に Cox 比例ハザードモデルを用いて, 空室が終了する確率（入 居リスク)のモデルを構築し有意な変数の推定を行う. 5.3 と同様の 方法で変数選択を行った後, 入居リスクモデルを作成した. そのパ

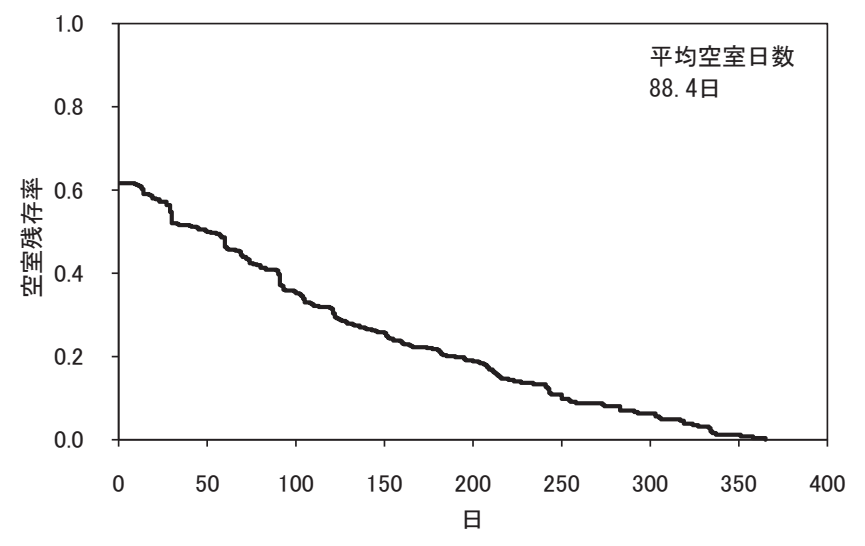

図 6 空室残存率曲線

表 5 入居リスクモデルのパラメータ

\begin{tabular}{|c|c|c|c|c|c|}
\hline \multirow[b]{2}{*}{ 項 } & \multirow[b]{2}{*}{ 推定值 } & \multirow[b]{2}{*}{$\mathrm{p}$ 值 } & \multicolumn{3}{|c|}{ リスク比 } \\
\hline & & & 值 & $\begin{array}{l}\text { 下側 95\% } \\
\text { 信頼限界 }\end{array}$ & $\begin{array}{l}\text { 上側 } 95 \% \\
\text { 信頼限界 }\end{array}$ \\
\hline 市況=回復 & 0.593 & 0.000 & 1.809 & 1.404 & 2.313 \\
\hline 市況=好況 & 0.826 & 0.000 & 2.284 & 1.683 & 3.055 \\
\hline エリア=千代田区 & -0.556 & 0.003 & 0.573 & 0.401 & 0.822 \\
\hline エリア=港区 & -0.350 & 0.017 & 0.704 & 0.533 & 0.937 \\
\hline 1 種あたり価格 & 1.224 & 0.000 & 3.402 & 1.740 & 6.579 \\
\hline 平均賃料 ～ & -0.871 & 0.044 & 0.418 & 0.180 & 0.977 \\
\hline 延床面積 & -0.996 & 0.010 & 0.369 & 0.172 & 0.787 \\
\hline 基淮階面積 & 0.862 & 0.044 & 2.369 & 1.025 & 5.312 \\
\hline 発生時築年数 & -1.124 & 0.000 & 0.325 & 0.193 & 0.547 \\
\hline 空調=個別 & -0.443 & 0.016 & 0.642 & 0.451 & 0.920 \\
\hline 光ケーブル=有 & 0.302 & 0.012 & 1.352 & 1.070 & 1.710 \\
\hline 基準階イメージ & 1.336 & 0.000 & 3.803 & 1.892 & 7.801 \\
\hline
\end{tabular}

モデルの $\mathrm{AIC}=4,637.5$

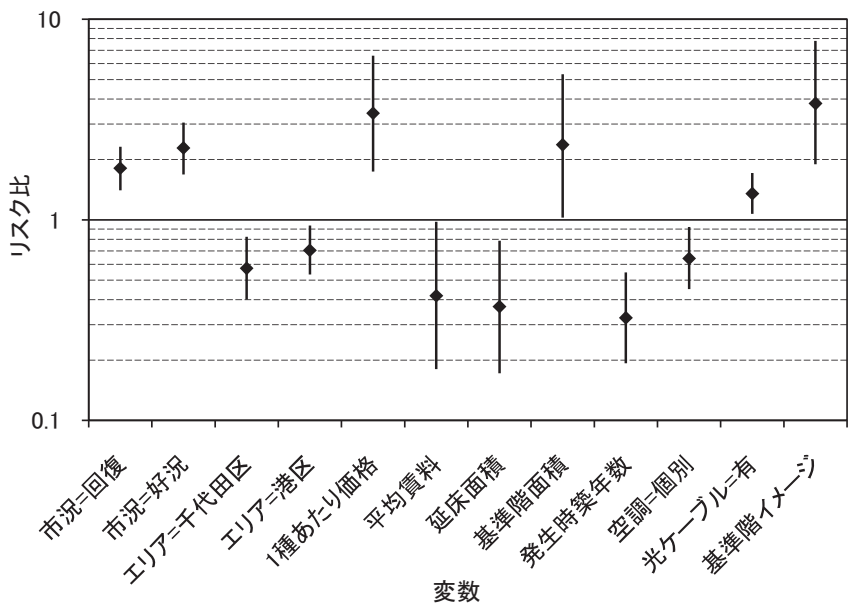

図 7 入居リスクモデルの各変数のリスク比と $95 \%$ 信頼区間

ラメータを表 5 に示す. 全ての変数で $\mathrm{p}$ 值が $5 \%$ の有意水準を満た している. 図 7 にリスク比とその 95\%信頼区間を示す.この場合, 值が 1 を超える変数が早く次のテナントが決まることに寄与し， 1 未満の変数は空室が継続する方向に寄与する. 信頼区間の幅も加味 して, テナントが決定しやすい変数といえるのは, 基準階イメージ,

1 種あたり価格, 市況のパラメータなどである. 筆者らの既往研究 4)では, 賃料推定モデルに基準階イメージが関わるケースがあったが, 今回の分析でも基準階イメージが入居決定に大きな因子となってい 
ることが，改めてデータから実証されたといえよう。1 種あたり価 格が高い所は立地条件が良いところが多いので，そのような場所に 立地するビルの空室は埋まりやすいのも納得できる。また, 今回新 たに定義した市況の変数であるが, 空室発生時点の市況が回復もし くは好況時であれば, それ以外の時の約 2 倍の確率で空室が埋まり やすくなることが示された. これらのリスク比の信頼区間は狭いこ とからも, 市況が空室日数に無視できない影響を与えていることは 確かといえよう. 逆に空室日数が伸びる方向に作用する変数は, 発 生時築年数や延床面積などである. 築年が経っている物件の空室日 数が伸びやすいのは理解しやすいが, 延床面積は解釈が難しい.

\section{7. まとめ}

本研究では, 東京都の主要 5 区内の賃貸用オフィスビル 52 件を対 象として, 生存時間分析を用いてそれらに入居寸るテナントの入居 期間と貸室の空室期間の分析を行った.

まず，オフィスビルマーケットの空室率と募集賃料が周期的に変 化していることを確認し, その現象に対する楕円近似のモデルを提 案し，マーケットの市況を 4 つの状態に分類した.

次に入居期間の分析を行った。平均するとテナントの入居期間は 13 年程度であった. 入居期間が長くなる方向に作用寸る因子は, 築 年数が長いこと, 外観イメージが良いこと, テナント用途が店舗な ど, 入居期間が短くなる因子は, 業種が不動産業のテナントなどで あった。

最後に空室期間の分析を行った．改修などの人為的な影響を考慮 して 1 年以内に空室が終了する貸室に限定した場合, 平均 88 日で次 のテナントが決定した. 新たなテナントが入居しやすい因子は, 基 準階のイメージが良いこと, 1 種あたり価格が高いこと, 市況が回 復・好況期にあることなど, 空室期間が延びる因子は, 築年数が長 い，延床面積が大きいなどであった．

今後の課題としては, 基準階の感性評価值の影響が空室日数と関 連が強かったので, 基準階のどのような属性が感性評価に寄与して いるかを明らかにしていくことがある.さらに，空室期間が 1 年を 超える貸室については, 空室発生要因が改修など人為的な要因とそ うでない場合を分けることと, 賃料などの時間変化する説明変数に ついては，できるだけその変化をトレースし，時間依存型の説明変 数を利用可能な生存時間分析手法を導入寸ることも課題である.

\section{謝辞}

本研究を行うにあたり, 株式会社ザイマックスの皆様と金多隆准 教授 (京都大学) から, ご援助と有益なご助言を受けました。また 楕円近似の実装では, 神山直之助教 (中央大学) の協力を得ました. さらに，匿名の査読者からも貴重なご意見をいただきました。

\section{注}

注1) Kaplan-Meier 推定法

説明変数を導入しないノンパラメトリックモデルの一つである.

打ち切りを含む $n$ 個のサンプルの中で, イベントが発生したサンプルの数 を $n^{\prime}$ とする. 一般にサンプルの観察開始時間は異なるが, 時間が 0 から 観察が開始されるよう各サンプルの観察開始時間をずらして揃えておく. 説明を簡単にするため, サンプルのイベントが発生するまでの時間はすべ て異なると仮定し, それらを $t_{1}<\cdots<t_{i}<\cdots<t_{n \prime}$ とする.サンプル $i$ は, $t_{i}$ 時間が経過した直後にイベントが発生するとし, その直前の未だイベン トが発生していない時点でのサンプルの集合をリスク集合 $R\left(t_{i}\right)$ と呼び, そのサンプル数を $r\left(t_{i}\right)$ とする. また, $t_{i}$ 時間後に発生するイベント数を $d\left(t_{i}\right)$ とする. リスク集合の数とイベント数には次の関係がある.

$$
r\left(t_{i+1}\right) \leq r\left(t_{i}\right)-d\left(t_{i}\right)
$$

ただしリスク集合の数はイベント発生によってだけではなく, 観察終了等 に伴う打ち切りによっても減少する.

生存率のカプラン・マイヤー推定量 $\hat{S}(t)$ は次のように表される.

$$
\hat{S}(t)= \begin{cases}1 & t<t_{1} \text { のとき } \\ \prod_{t_{i}<t} \frac{r\left(t_{i}\right)-d\left(t_{i}\right)}{r\left(t_{i}\right)} & t \geq t_{1} \text { のとき }\end{cases}
$$

$t$ に対する $\hat{S}(t)$ をプロットすることで, 生存率の推定曲線が描ける.

注2) Cox 比例ハザードモデル

生存時間に影響を及ぼす複数の因子の影響を解析する事を前提としたモデ ルであり, セミノンパラメトリックモデルの一種である.

いま, 二つのハザード $h_{1}(t), h_{2}(t)$ において, 全ての可能な $t>0$ に対し て, $h_{1}(t)=c h_{2}(t)$ が成り立つとき, 二つのハザードは比例すると言う. ここで $c$ は時刻 $t$ に依存しない定数であるとする.

説明変数 $\mathbf{x}=\left(x_{1}, x_{2}, \ldots, x_{m}\right)$ を持つハザードを $h(t \mid \mathbf{x})$ とし, $\mathbf{x}$ を変数とす る関数 $f(\mathbf{x})$ と, あるハザード $h_{0}(t)$ が全ての $t>0$ と $\mathbf{x}$ について

$$
h(t \mid \mathbf{x})=h_{0}(t) f(\mathbf{x})
$$

が成り立つとき, この式を比例ハザードモデルと呼ぶ. Cox 比例ハザード モデルは, $\boldsymbol{\beta}=\left(\beta_{1}, \beta_{2}, \ldots, \beta_{m}\right), f(\mathbf{x})=\exp (\boldsymbol{\beta} \mathbf{x})$ として次の回帰モデルとし て定義される.

$$
h(t \mid \mathbf{x})=h_{0}(t) \exp (\boldsymbol{\beta} \mathbf{x})=h_{0}(t) \exp \left(\sum_{i=1}^{m} \beta_{i} x_{i}\right)
$$

なお， $\mathbf{x}$ が全て 0 の場合のハザード $h(t \mid \mathbf{x})=h_{0}(t)$ を, ベースラインハザ ードと呼ぶ.

上式のパラメータ及を求める方法を以下に示す. 注 1)同様に, 打ち切りを 含む $n$ 個のサンプルの中で, イベントが発生したサンプルの数を $n^{\prime}$ とす る。説明を簡単にするため, サンプルのイベントが発生するまでの時間は すべて異なると仮定し，それらを $t_{1}<\cdots<t_{i}<\cdots<t_{n}$ ，とする，ある時間 $t_{i}$ の直後にイベントが発生するサンプル $i$ のハザードと, リスク集合 $R\left(t_{i}\right)$ に含まれるサンプルのハザードの総和の比を $L_{i}$ として次式で表す.

$$
L_{i}=\frac{h\left(t_{i} \mid \mathbf{x}^{i}\right)}{\sum_{j \in R\left(t_{i}\right)} h\left(t_{i} \mid \mathbf{x}^{j}\right)}
$$

すべてのイベントの発生時間での $L_{i}$ の総積 $L=L_{1} \times \cdots \times L_{i} \times \cdots \times L_{n}$ ， 部分尤度と呼び，それを式(1)(2)を用いて書き換えると以下で表される.

$$
L=\prod_{i=1}^{n \prime} \frac{h\left(t_{i} \mid \mathbf{x}^{i}\right)}{\sum_{j \in R\left(t_{i}\right)} h\left(t_{i} \mid \mathbf{x}^{j}\right)}=\prod_{i=1}^{n^{\prime}} \frac{\exp \left(\boldsymbol{\beta} \mathbf{x}^{i}\right)}{\sum_{j \in R\left(t_{i}\right)} \exp \left(\boldsymbol{\beta} \mathbf{x}^{j}\right)}
$$

Cox 比例ハザードモデルのパラメータ $\boldsymbol{\beta}=\left(\beta_{1}, \beta_{2}, \ldots, \beta_{m}\right)$ は, 上の部分尤度 $L$ を最大化する值として, Newton-Raphson 法などの非線形最適化法で求め ることができる．部分尤度を最大化するとは, リスク集合 $R\left(t_{i}\right)$ のサンプ ルの中で, サンプル $i$ のハザードが最も高くなるよう, $\boldsymbol{\beta}$ を決定すること を意味する．また， ベースライン八ザード $h_{0}(t)$ が約分により消え，その 関数形を仮定する必要がなくなっている.この意味で Cox 比例ハザードモ デルは, セミ・パラメトリックモデルと呼ばれる.

注 3) 回帰分析では決定係数によりモデルの評価を行うことができる. 決定係 数を求めるには, 目的変数の真の值と予測值が必要である. 一方, Cox 比 
例ハザードモデルでは式(3) に示すように, ベースラインハザード関数 $h_{0}(t)$ の具体的な形を想定することなくモデルのパラメータを決定するの で，八ザードの值は予測できない，よってモデルの評価に決定係数は使え ず，尤度に基づく方法が用いられる。一般には AIC を用いたステップワイ ズ法による逐次的な変数選択法が用いられており ${ }^{6}$, 本研究でもそれに従 っている.

\section{参考文献}

1) J. L. Glascock, S. Jahanian and C. F. Sirmans, An Analysis of Office Market Rents: Some Empirical Evidence, AREUEA Journal, 18(1), 1990.

2) 中村良平, オフィスビル賃貸料のヘドニック分析, 岡山大学経済学会雑 誌, 25(3), pp.239-256, 1994

3) 有馬昌宏, 第 8 章 オフィス市場の理論と分析, 都市と土地の経済学，日 本評論社, pp.139-156, 1995.

4) 瀧澤重志, 材木敦, 加藤直樹, 具源龍 : 新橋に立地するオフィスビルの 感性評価を考慮した賃料分析，日本建築学会計画系論文集，73，627， pp.1053-1059, 2008.5

5) 高橋宣行, 瀧澤重志, 加藤直樹, 具源龍 : 賃貸用オフィスビルのエント ランスホールに対する感性評価の CAEP を用いた分析, 日本建築学会計 画系論文集，74，640，pp.1403-1410，2009.6.
6) 中村剛: 医学統計学シリーズ 3 Cox 比例ハザードモデル, 朝倉書店, 2001 .

7) E. L. Kaplan and P. Meier: Nonparametric estimation from incomplete observations, Journal of the American Statistical Association, 53, pp.457-481, 1958 .

8）小松幸夫, 島津護 : 竣工記録に基づいた事務所建物の寿命調查, 日本建 築学会計画系論文集，565, pp.317-322，2003.3.

9) 伊藤香織, 曲㴊英邦：テナント交替の確率モデルー有限時間空のデータ による最尤推定一, 都市計画学会学術研究論文集, 58, pp.343-348, 1998.11.

10) D. R. Cox: Regression models and life-tables. Journal of the Royal Statistical Society. Series B (Methodological), 34(2), pp.187-220, 1972.

11) 村山隆英, 海道清信, 東樋口護, 三村浩史 : 都市圈におけるオフィス開 発市場の特性分析による発展形態類型に関する研究一日本および米国の 市場データ分析と比較考察から一, 日本建築学会計画系論文集, 528, pp.187-193, 2000.2

12) 内上誠：景気循環論入門，晃洋書房，2004.

13) 松原周平, 加藤直樹, 瀧澤重志, 神山直之, 杉本和也, 山方俊彦 : 空室 率と募集賃料の時系列データに基づく東京 23 区主要オフィスエリアのク ラスタリング, 日本オペレーションズリサーチ学会 2008 年春季研究発表 会, pp.76-77, 2008. 